\title{
Robert Wise's The Day the Earth Stood Still Part I: A Religious Film?
}

\author{
By Anton Karl Kozlovic
}

Fall 2013 Issue of KINEMA

ROBERT WISE'S THE DAY THE EARTH STOOD STILL Part I: A RELIGIOUS FILM?

\begin{abstract}
Science fiction (SF) films have frequently been the home for subtextual biblical characters, particularly Christ-figures. Crafting these sacred subtexts can make the difference between an ordinary film and an exceptional one. This investigation intends to explore the religious and other dimensions of the $1951 \mathrm{SF}$ cult classic The Day the Earth Stood Still directed by Robert Wise. In Part 1 of this analytical triptych, the film's reception as a UFO film with political, artificial intelligence (AI), police and philosophical dimensions was canvassed. It was argued that Wise's film contains all of the above genre dimensions; however, it can be more fully appreciated as a profoundly religious film wrapped in contemporary scientific garb. The forthcoming parts will explore the factual elements of this proposition in far greater analytical detail.
\end{abstract}

Introduction: SF and Sacred Storytelling

Historically speaking, science fiction $(\mathrm{SF})$ films $^{(1)}$ have harboured numerous hidden biblical characters in typically covert forms. For example, Barry McMillan described many an SF alien as "a 'transcendent' being - a benign entity who brings wisdom and knowledge, the imparting of which brings resolution, insight and the beginnings of personal or political harmony" (360). Whilst Bonnie Brain argued that: "The ascendancy of the aliens derives strongly from their aura of religious authority. Teachers, mystics, priests, or prophets, capable of "miracles" and, in some cases, "resurrection," these aliens flirt with divinity" (226). Yet in many cases, they do not just flirt with divinity, they are contemporary representations of divinity in subtextual form.

The most famous Western exemplar is the Christ-figure (Kozlovic Structural), that is, on-screen characters who, in significant ways represent the life, actions or attitudes of the historical Jesus Christ. Even if they do not look like him, or they are located in "strange" places that audiences are accustomed to perceiving in traditional Jesus films attempting to recreate the ancient past (Humphries-Brooks; Kinnard and Davis; Reinhartz Hollywood; Stern, Jefford and DeBona; Tatum; Walsh). Adele Reinhartz described this subtextual phenomenon in the following way:

....Jesus is not portrayed directly but is represented symbolically or at times allegorically. Christ figures can be identified either by particular actions that link them with Jesus, such as being crucified symbolically (Pleasantville, 1998), walking on water (The Truman Show, 1998) or wearing a cross (Nell, 1994; Babette's Feast, 1987). Indeed, any film that has redemption as a major theme (and this includes many, if not most, recent Hollywood movies) is liable to use some Jesus symbolism in connection with the redemptive hero figure (Silver 189).

According to Father Peter Malone:

"Jesus-figure" refers to any representation of Jesus himself. "Christ-figure" describes any figure in the arts who resembles Jesus. The personal name of Jesus (in line with contemporary spirituality, thought and practice) is used for the Jesus-figure. The title "Christ" - the "Messiah," or the "Anointed One" - is used for those who are seen to reflect his mission. In cinema, writers and directors present both Jesus-figures and Christ-figures (59-60).

In short, the "idea of 'the Christ-figure' seeks to counter the straitjacketing of Jesus in physical correspondence to a [historical] stereotype" (Coates 80 ).

The SF genre provided the perfect home for religious storytelling following the decline of the 1950s rash of biblical epics triggered by Cecil B. DeMille's watershed production, Samson and Delilah (1949), and especially when coupled with the nuclear annihilation concerns of Cold War America (Jowett). As Hugh Ruppersburg noted regarding alien Messiahs: "science fiction films of the 1970s and '80s serve the same 
function as the biblical epics of the 1950s and '60s' (165), and well beyond it. The only difference is that the religious agenda of these SF films were artfully hidden, but of such powerful significance and effect that they were capable of turning an ordinary film into an exceptional one. Even when the specific Christ-figure motif was missing, ignored or denied, "aliens have become the cinematic incarnation of the dei ex machina" (Brain 227) and thus worthy of scholarly examination in its own right because of it.

\section{Sacred Subtexts, Science Fiction and Ufology}

What exactly are sacred subtexts (aka holy subtexts; divine infra-narratives)? In essence, they are hidden religious figurations built into films that add new layers of meaning to the storytelling, but they only become detectable once consciously sensitised to their existence. This phenomenon has been described as "anonymous religiousness" (Gallagher 151) or the pursuit of "overtly religious themes in a secular 'wrapper'" (Ellis 304). Ontologically speaking, subtexts exist because storytelling narratives have a dual nature. Namely, an overt plot plus a covert storyline of varying complexity that is comparable to the metaphorical or symbolic within literature; however, "the narrative and infra-narrative (or text and subtext) are not two separate entities (there is, after all, only one film); think of them, rather, as two concentric circles, the infra narrative being within the narrative" (Dick 129).

Through this intimate narratological arrangement, putatively secular films can engage in serious religious storytelling without necessarily appearing "religious," thus putting off atheists, non-believers, or the religiously wounded with unforgiving dispositions. Moreover, a "character needn't be consciously aware of his shadings of the truth or the hidden meanings in his words or actions for there to be subtext or for us to become aware of it" (Howard 189). The public frequently misses these hidden sacred subtexts in SF films, especially by those viewers who consider "science" and "religion" to be mutually exclusive categories diametrically opposed to each other.

Kenneth Arnold's sighting of strange objects in the sky on 24 June 1947, which the press quickly labelled "flying saucers" (Lewis xxviii), triggered the genesis and subsequent discussion of popular film's contribution to the UFO phenomenon-cum-alien literature (Baker; Spencer). As Peter J. Morris put it: "With such titles as The Thing and The Day the Earth Stood Still these films set the style and pattern of numerous Hollywood nasties based around crashed flying saucers and man-eating aliens" (68); yet ironically, The Day the Earth Stood Still is still frequently misunderstood because it is not about a crashed UFO or about a man-eating alien. Rather, it is about a peace-loving, gift-giving, intergalactic ambassador who purposely visited Earth, arrived safely, but was subsequently alienated, and killed (temporarily) before returning home. Albeit, film publicists used poster designs that pandered to audience fears of the other, contrary to the film's enlightened content (see Figure 1).

For the purposes of this investigation, essential film, SF and religion literature was selectively reviewed and integrated into the text to enhance narrative coherence (albeit, with a certain reportage flavour). Utilising humanist film criticism as the guiding analytical lens (i.e., examining the textual world inside the frame, but not the world outside the frame - Bywater and Sobchack chpt. 2; Telotte Science chpt. 2), Robert Wise's SF classic The Day the Earth Stood Still (1951) was chosen and closely examined to reveal its various religious (and related) genre dimensions. But why bother investigating a movie that is over half-a-century old? In addition to being frequently misunderstood, it has been lauded as "the American cult favorite" (BellMetereau 125) and "one of the finest science-fiction films of the 1950s" (Baker 62) that had "undermined the standard anti-alien propaganda later associated with the majority of Hollywood science fiction films" (Bell-Metereau 115).

Therefore, one of the research aims herein is to resolve the debate in the affirmative of "whether this is a Jesus allegory" (Simpson 344), or not. As Jerome F. Shapiro argued: "Scholars often refer to The Day the Earth Stood Still as an example of apocalyptic filmmaking. I believe, however, that it has much more in common with biblical testaments" (Atomic 81). One can only agree with him and proceed to demonstrate that assertion in even greater scholarly detail than done previously. But not before briefly canvassing the multiple genre perceptions of this favourite fifties film, most notably as a political film that is "just as relevant today as was the day it was released" (Nash and Ross 586).

\section{The Day the Earth Stood Still as a Political Tract}

Many scholars were moved by this cult classic because of its "almost documentary flavor" (Stal npn), which 
was loosely based upon Harry Bates' 1940 novelette Farewell to the Master (Bates 1994). It was subsequently considered "[o]ne of the first and best antiwar films" (Stacy and Syversten 135) that "satirises the paranoia of the McCarthyite USA" (Cranny-Francis 84) "by configuring its extraterrestrials as a neutral, largely benevolent force, depicting the dead-end future of warfare, and advocating a relatively pacifist message even as the United States was engaged in the Korean War" (Bell-Metereau 115). As such, "the film is on one level an allegory about the need for humanity to find new ways of resolving its conflicts if it is to avoid destroying itself" (Hewitson 283). These messages alone helped make it "one of the few real sf classics" (Brosnan Future 83) and "something of a pop-culture standard in recent years, well known even outside science fiction and film buff circles" (Zebrowski 121). Indeed, as Robert Cettl argued: "The Day the Earth Stood Still had connected so much with the public as to virtually initiate an identifiable movement within the developing genre. Atomics and politics were now symbiotic" (4).

Not surprisingly, homage to it has occurred in popular songs, TV series and feature films. For example, in the alien invasion opus, Independence Day, a scene from The Day the Earth Stood Still was playing on TV inside a caravan in a trailer park wherein both the robot Gort and the alien Klaatu foreshadowed the film's own unique alien threat-to-come (Badmington 51). In the live-action comedy, The Flintstones in Viva Rock Vegas, the small, green, flying alien visitor, Gazoo (voice of Alan Cumming) crash-landed on Earth and was trapped inside his spaceship. He cried out for help using the signature phrase employed by Helen Benson (Patricia Neal) in The Day the Earth Stood Still to stop Gort (Lock Martin) annihilating Earth, namely: "Gort! Klaatu barada nikto." Gazoo was subsequently liberated by Fred Flintstone (Mark Addy) and Barney Rubble (Stephen Baldwin) and continued his scientific sojourn in their prehistoric company. Even the disembodied red lips and white teeth at the opening of The Rocky Horror Picture Show sang about him, namely: "Michael Rennie was ill the day the earth stood still, but he told us where we stand."

In its own day, The Day the Earth Stood Still won the Golden Globe Award for the Best Film Promoting International Understanding (Fischer 686), and it was considered "something of an anomaly among the more typical science fiction films of the period" (Torry 11). This is even more remarkable because in "the xenophobic fifties films, the invading "foreigners" were a common enemy that served to reaffirm the prevailing American myths of national supremacy, moral superiority, and optimism in the face of doom" (Brain 219). Yet, in this filmic case, these traditionally positive pro-American values were deemed not so positive when viewed from a higher viewpoint; physically, politically and symbolically speaking. As Tony Magistrale pointed out concerning Klaatu's warning: "it is delivered in Washington, DC, subtly indicating the United States as the most aggressive nation on the earth and thus in need of the most dire warning" (84). Indeed, Klaatu's alien device that was destroyed by a trigger-happy American soldier "was a gift for your President. With this he could have studied life on the other planets" (see Figure 2).

No wonder Garyn G. Roberts claimed that Wise's film had "refined and revolutionized the formula" (130) of the science fiction invasion film and had provided "the perfect counterpoint" (138) to that notably negative SF sub-genre. For Ziauddin Sardar, The Day the Earth Stood Still was "the antithesis to Invasion of the Body Snatchers" (11) especially with its "pacificist, internationalist moral" (11) that was firmly rooted in the "pacific traditions of Western Christendom" (12).

Traditionally speaking, the movie was not only interpreted as a UFO film but also as an anxious, cathartic reflection upon the nuclear age and its burgeoning atomic testing program. This dramatic rendering of nuclear apocalyptic fiction contained powerful political resonances as it explored the rampant geo-political anxieties of the Cold War era (Gabbard; Henriksen; Shaw). As director Robert Wise himself claimed: "it was very obvious that the film was making a political comment. All of us involved in The Day the Earth Stood Still were very concerned about the threat of atomic war and the indiscriminate or accidental use of atomic power" (Pohl and Pohl IV 114). Indeed, for Mick Broderick, Klaatu's famous:

...authoritarian ultimatum...may also read as a then-contemporary metaphoric interpretation of American foreign policy - a sort of post-WWII proclamation from the United States to the remaining global community, having monopolized (and demonstrated its willingness to use) nuclear weaponry... (17).

Alternatively, "Klaatu's message sounds like a virulent version of Cold War containment policy" (Flesher and Torry par. 10), which for Dennis Barone was "analogous to the McCarthy/Taft view" (298) with its 


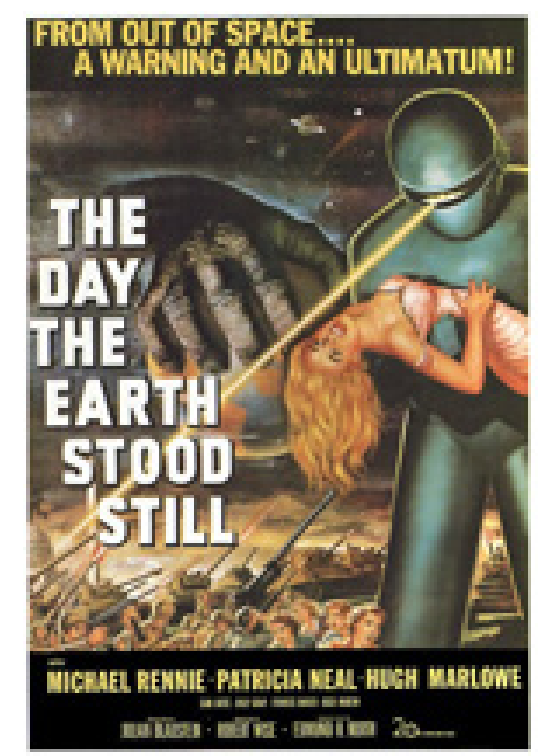

Figure 1: The Day the Earth Stood Still Poster

"obvious signs that point to a possible linkage of Klaatu to a New Deal intellectual" (208).

These political claims were especially potent against the historical backdrop of the Korean War, Cold War politics, the Red Scare, and American McCarthyism. Therefore, what "emerges from the script is a paradigm for communicating reason in an age of reactionary politics... [and where the] science fiction genre thus became the avenue of choice for a provocative political statement" (Shaw 50), albeit, a "progressivist vision" (Shapiro Atomic 82). As Jon R. Stone succinctly summed it up:

Released during the "hot" period of the Korean War, this mysteriously gripping film used aliens from a distant planet as its messengers. These aliens, led by Klaatu (Michael Rennie), travelled to Earth with a special mission of warning: human aggression and nuclear terror must not expand into the solar system. "Man," they explained, was not only a threat to his own kind, but he and his growing nuclear arsenal were a threat to all intelligent life. Resistance to the alien mission by the US military only confirmed their message: humans were hell-bent on destroying themselves and thus were in need of extraterrestrial mediation (71).

This interpretation is especially important considering the political subtext of America's misappropriation of science for military purposes; and presumably the militarisation of outer space, which in the film had worried the other planets enough to send Klaatu to Earth with his dire warning. As Tony Magistrale argued, The Day the Earth Stood Still "remains one of the few films from the era where all forms of patriarchal authority are suspect, particularly the military and the government officials who share in a collusion of ignorance" (85).

However, for Lee Pfeiffer, the "film suffers from a naive pacifist message that mankind should destroy its nuclear weapons. Sounds good in theory, but it looks like Stalin didn't get Klaatu's memo" (182); but he would have got it if the only other option was to "face obliteration" when Earth was "reduced to a burned out cinder" as Klaatu dramatically warned (see Figure 3).

Klaatu subsequently departed the planet leaving Earth to make a monumental decision regarding its future. Hopefully, "Through his intervention, the alien forcefully changes human society, ushering in a new era by compelling humanity to master its instinct to fear and aggression. The way in which society's reformation is imagined as taking place is both secular and premillennial" (Hewitson 283).

For John Brosnan, Robert Wise's political commentary was not very enlightening: "The idea of placing our basic human rights in the custody of a machine, or any 'superior force', is not only an admission of defeat 


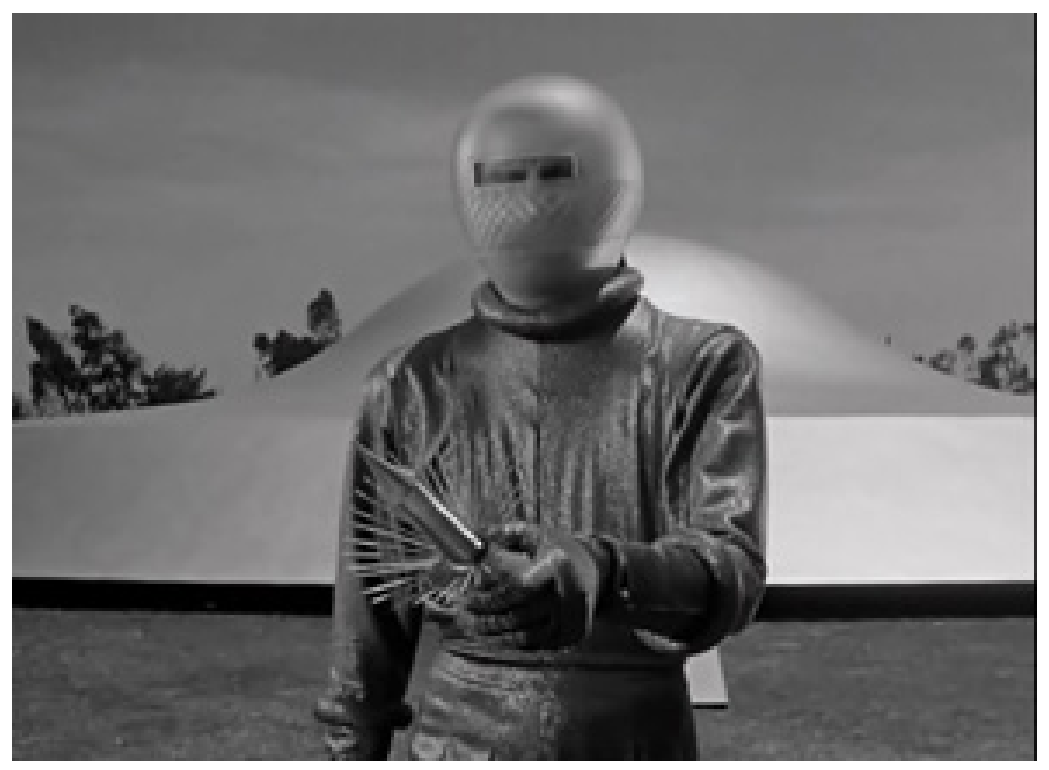

Figure 2: Klaatu's Gift

but also one which smacks of totalitarianism" (Future 84). However, Brosnan overstated his case here for Klaatu (and Gort) were benevolent; their intergalactic federation deliberately chose this governing method, with Klaatu claiming: "We do not pretend to have achieved perfection, but we do have a system - and it works." Nor were they interested in Earth's internal politics, except in one aspect that had the potential to seriously affect the cosmic neighbourhood - aggression. Furthermore, Klaatu acknowledged that humanity had the right to be free: "It is no concern of ours how you run your own planet," and which "does not mean giving up any freedom, except the freedom to act irresponsibly." So, in this sense, it was an act that was "less altruistic than space-preservational" (Sobchack 192) as humanity is compelled to rigidly conform to the universal requirement of peace via discipline from friends in high places.

Politically speaking: "Klaatu's answer is [Thomas] Hobbes's answer: leviathan, a state structure sufficiently powerful to compel compliance and thus guarantee survival and peace" (Gianos 136). Therefore, "the humbling of humanity is not to be taken as a defeat but rather as a victory. Humanity is now free to discover its true self with respect to the powers and forces that run through the cosmos" (Lucanio 45). John Brosnan's (Future 84) totalitarianism concern appears to be the film critic equivalent of Boylston Tompkin's concern, namely:

...the unwillingness of most science-fiction film makers to venture outside popular prejudices concerning the nature of humanity's relationship to the cosmos. We do not like to think that God - or an alien so far removed from our limitations as to seem godlike - may not be motivated by any of our primary concerns. We prefer Him (or Her or It) in a presentable human envelope. But we thereby deny God His Godhood - the limitless freedom of choice that a mature theology ascribes to Him as a first principle (quoted in Siegel and Suares 20).

\section{The Day the Earth Stood Still as an AI Advocate}

Less famously but just as valid as a political interpretation, Wise's film has also been seen as an Artificial Intelligence (AI) film in which Gort is just another example of powerful pseudo-sentient technology amongst a filmic sea of rogue robots, crazy computers and angry androids (Kozlovic Technophobic). Wise had replaced the patriarchal authority of earthly militaries and governments with an alien AI authority (i.e., the physical embodiment of cold, ruthlessly efficient rationality). The solitary, humanoid alien Klaatu with a genteel soul was suave, charming and cosmopolitan, but he achieved his (and the other planets) regulatory control via Gort, his interplanetary travel companion-plus-AI enforcer (Figure 4).

Gort is a "tall, hulking humanoid robot" (Perkowitz 96), the alien technological equivalent of the Cyclops of 


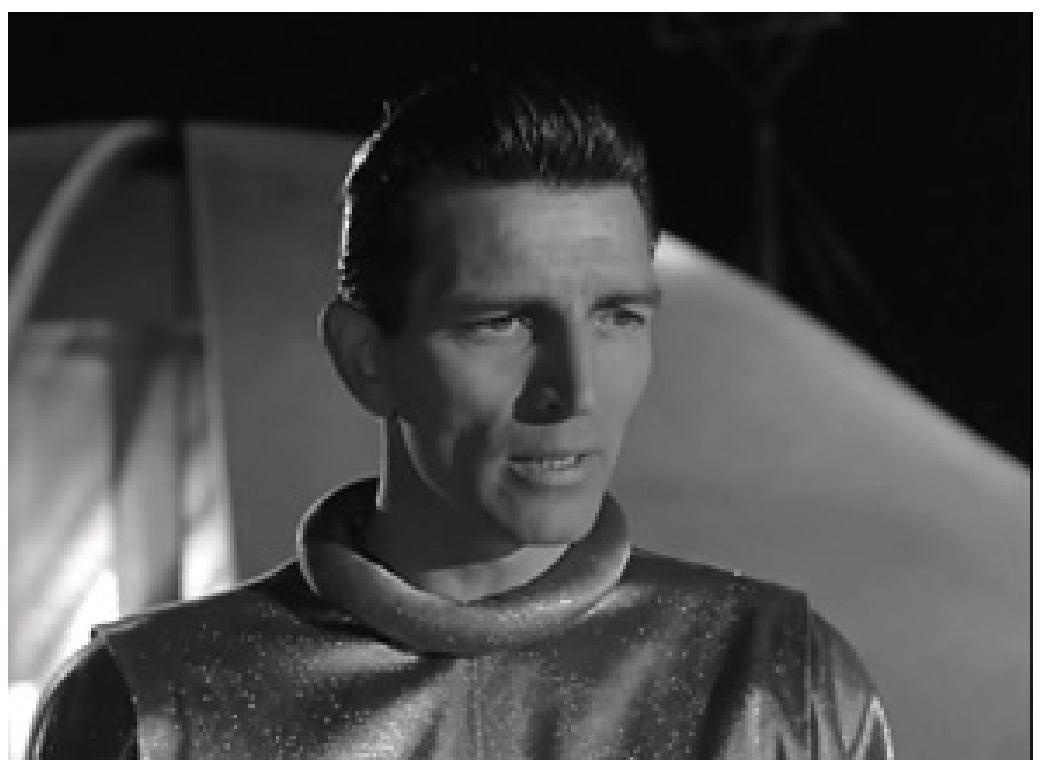

Figure 3: Klaatu in Warning Mode

Greek mythology who was "neither a pod or a blob but a deluxe model human" (Biskind 151), and extremely powerful, as a concerned Klaatu told Helen Benson: "There's no limit to what he can do. He could destroy the Earth," he could reduce it "to a burned out cinder." In effect, the cybernetic Gort could think humanity out of existence if mankind transgressed the prescribed cosmic laws of "correct" inter-planetary behaviour. Today, Gort is one of filmdom's most famous robot stars alongside the skeletal Maria from Metropolis, Robbie the Robot from Forbidden Plant and the (unnamed) Robot from the TV series Lost in Space and its eponymous film adaptation. "Indeed, for many students of the genre, Gort...may be the most memorable...figure of postwar science fiction" (Telotte Replications 113-14), and a good example of AI "Alien chic" (Biskind, 151).

Furthermore, The Day the Earth Stood Still was a rare cinematic exemplar of Asimovian faith in intelligent technology because highly advanced biological beings willingly put their faith, trust and very physical existence into the hands of machine others. As Klaatu proudly proclaimed: "In matters of aggression we have given them absolute power over us. This power cannot be revoked." In effect, this meant that: "If men of humanity are ignored, then humanity will be at the mercy of the elemental forces of blind technology" (Rogerson par. 3); albeit, a pre-programmed threshold rather than totally blind, which helps explain why Tony Magistrale considered it one of the best "techno-horror" (84) films of the 1950s. The threat Gort poses to Earth "metonymically indicates the threat Earth poses to itself through disharmony" (Cranny-Francis 85), in particular, humanity's aggressive continuance of nuclear weapons proliferation coupled with its planned forays into outer space.

For John Brosnan: "The idea of submitting to the rule of a race of implacable robot policemen is at best an unusual form of liberalism" (Day 157); especially as it showed technological superiority embodying alienand-universal ethical and moral superiority. Ironically, it was this moral superiority that justified Klaatu's ultimatum, or as Gerald E. Forshey put it, Klaatu: "threaten[ed] to destroy the earth if the earth does not stop threatening to destroy itself" (33). The writer argues that it was cosmic self-defence to the threat of intergalactic pollution from Earth in the form of violence that was the true justification for Earth's potential annihilation. This turns Klaatu and Gort into harbingers of enlightened despotism, the alien equivalent of the philosopher-king of Plato's Republic; even if it ultimately meant that humanity was "locked into a global straight jacket" (Barone 202) because of it, and everyone else's, social good.

It was also appropriate that Klaatu demonstrated his technological power by choosing to focus upon Earth's power source by highlighting:

...the world's reliance upon electricity. By shutting down the power grid and making the earth 
stand still, the alien indicates that the most important feature that separates superpowers from developing nations, and thereby poses the greatest threat to the universe, is technology itself - without electricity, technology (and, by extension, the atomic threat) is essentially negated (Magistrale 84).

Alien technology (i.e. Gort and lethal flying saucer) being the instrumental means of monitoring and enforcing the continual negation of Earth's testosterone-driven aggressiveness and other destructive militaristic impulses, but which an automated AI device does not inherently suffer.

\section{The Day the Earth Stood Still as a Police Film}

The Day the Earth Stood Still is an unusual Cold War film in that "the conflict-ridden Earth is presented as the potential predator" (Cranny-Francis 84). As Klaatu lamented: "soon one of your nations will apply atomic energy to spaceships. That will create a threat to the peace and security of other planets. That of course we cannot tolerate...by threatening danger, your planet faces danger, very grave danger." This potentially disturbing cosmic situation necessitated interplanetary control via "police robots" (Lewis 101). Gort, as the "ultimate product of enlightenment science" (Magistrale 86), is thus an intergalactic "peacekeeper" (Torry 15), "an outer space enforcer" (Cousineau 66) who acts as a pest exterminator roaming the Universe in his planet-killing saucer seeking out aggressive life-forms who threaten the cosmic peace (see Figure 5).

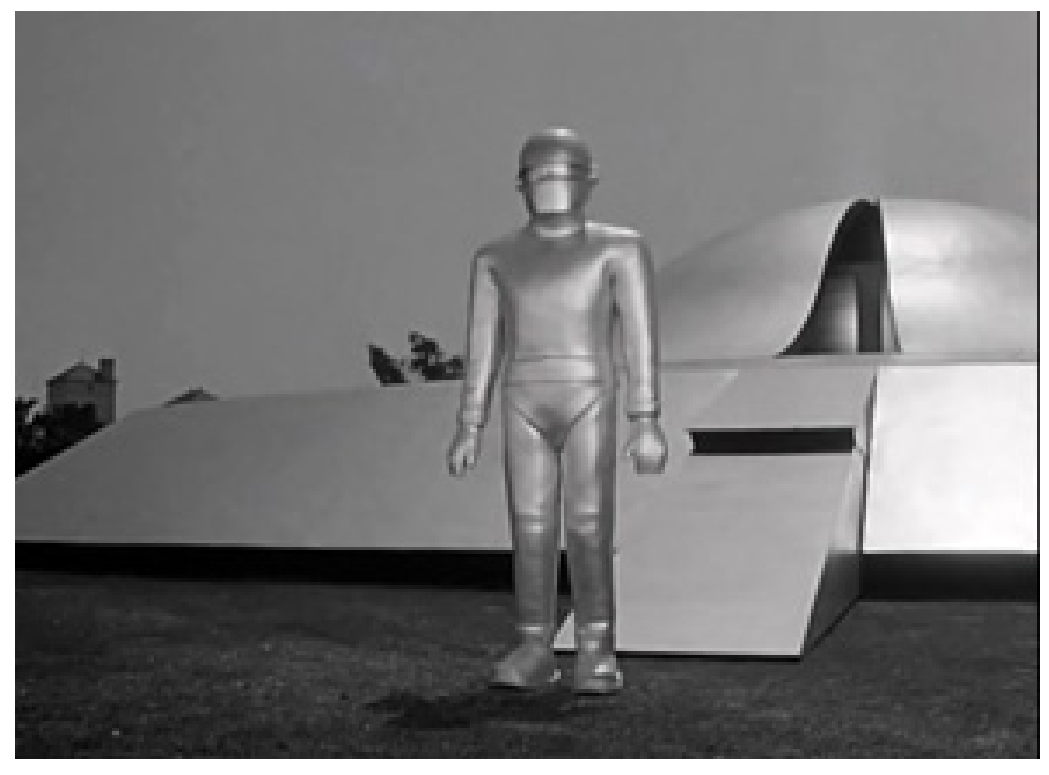

Figure 4: Gort and Interplanetary Spaceship

As Klaatu justified this situation to the assembled peoples prior to his earthly departure:

There must be security for all or no one is secure. This does not mean giving up any freedom, except the freedom to act irresponsibly. Your ancestors knew this when they made laws to govern themselves and hired policemen to enforce them. We of the other planets have long accepted this principle. We have an organization for the mutual protection of all planets and for the complete elimination of aggression. The test of any such higher authority is of course the police force that supports it. For our policemen, we created a race of robots. Their function is to patrol the planets in spaceships like this one and preserve the peace.

Visually speaking, Gort was "a perverse visualization of the medieval knight in shiny armor" (Sobchack 78). His large size, silvery colour and Cyclops eye certainly provided him "with an air of menacing omnipotence appropriate to his role of judge and potential executioner" (Dubeck, Moshier and Boss 58). This visual air of menace was enhanced sonically by "the Gort theme, which utilises the low pitch commonly used to signify threat and also great power" (Cranny-Francis 85). Whilst both Gort and Klaatu's extra-terrestrial origins were further sonically underscored by Bernard Hermann's haunting score, particularly his artistic use 
of an electronic theremin to signify otherworldliness, psychological strangeness, and potent threat potential (Husarik).

Once physical aggression had been detected, Gort would act automatically against the aggressor, including the disintegration of entire planets if need be. Thus the cosmic Utopia is maintained, or as Klaatu proudly claimed: "The result is, we live in peace, without arms or armies, secure in the knowledge that we are free from aggression and war, free to pursue more profitable enterprises." This state of things is achieved albeit even if under an "interplanetary police state" (Hendershot 31) ruled by the galactic equivalent of ultraconservatives, or what John Brosnan disparagingly called "a community of interplanetary busybodies" (Future 83). Yet, as John C. Lyden pointed out: "we were the real enemy in this film, as humans reacted with fear to Klaatu and tried to destroy him, demonstrating that humans are just as violent as he said we were. In this case, it is the humans in the film who project their own violence onto the alien, imagining that he is the threat" (206); a "monster" according to the film's various radio announcers. Ultimately, this machine-augmented form of enlightened policing-cum-cosmic social engineering resulted in the Universe enjoying peaceful coexistence for centuries; and a big decision for humanity to make regarding joining the universal order, or perishing.

\section{The Day the Earth Stood Still as Audiovisual Philosophy}

In another alternative reading, the film was considered a cautionary tale directed at the nuclear barbarians of the 1950s by "presenting moral issues instead of explosions" (Perkowitz 96-97). It was deliberately designed to "pull our moral socks up" (Brosnan Future 60) with Klaatu acting "like a sort of cosmic conscience" (Tompkins 19); especially when as the incognito Mr. Carpenter, Klaatu's Earth identity, told a radio interviewer at the saucer site that: "I am fearful when I see people substituting fear for reason" before being unceremoniously cut off mid reply by the sensation-seeking journalist.

Interestingly, Mark Jancovich claimed that: "For Klaatu, human emotions have no foundation or validity, and it is only rational thought which has any positive value" (41-42) and so the film's "criticism of American society is simply that it is not rational enough, and it calls for the repression of individual feelings, interests and desires" (Jancovich 41). For Peter Biskind, this made "Brainy Klaatu, kin to the Krel" (154) of Forbidden Planet; and yet, the interpreted repudiation of earthly emotion is too severe a reading of the film. The repression of individual feelings, interests and desires only applied to destructive human aggression! Klaatu valued other ideals as demonstrated when he and Bobby Benson visited the Abraham Lincoln memorial (Washington DC) and he endorsed the "great words" of this "great man," and told Bobby "that's the kind of man I'd like to talk to" (see Figure 6).

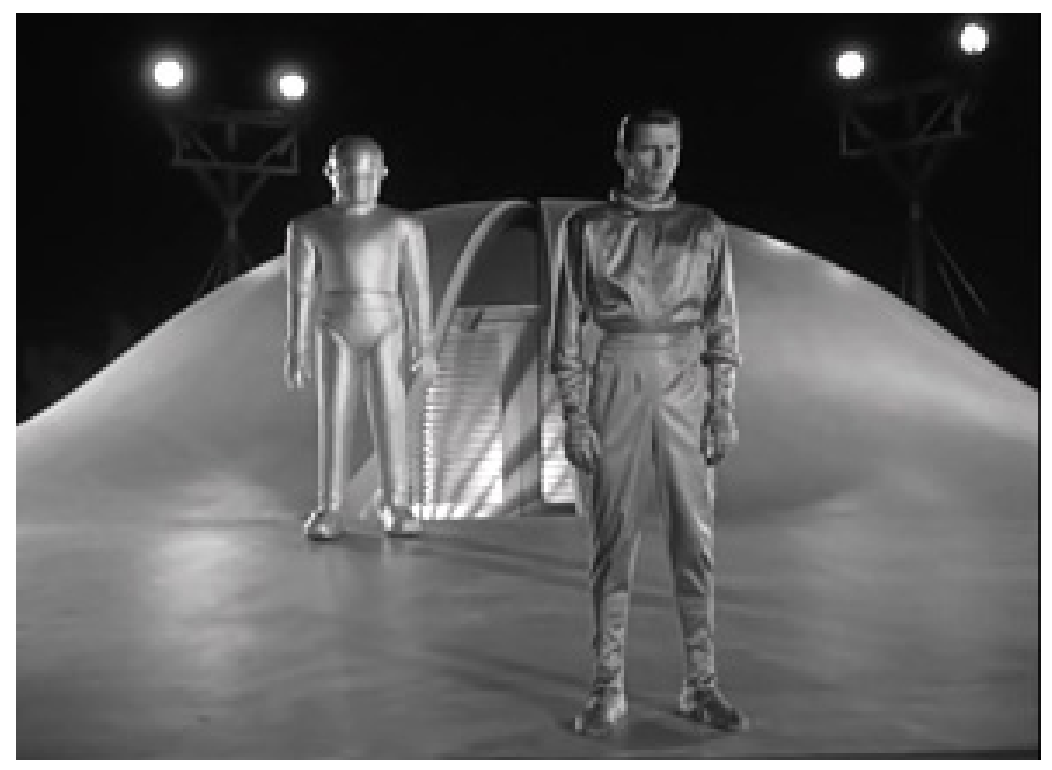

Figure 5: Gort, the Power behind Klaatu 
Thus prompting Klaatu's search for "the greatest man in America today," "the greatest philosopher, the greatest thinker," which young Bobby Benson (Billy Gray) interpreted as "the smartest man in the whole world...Professor Barhardt I guess. He's the greatest scientist in the whole world."

Overall, The Day the Earth Stood Still had tried to encourage humanity to reflect upon the momentous consequences of the nuclear path they were taking, and so he urged them to find a better solution to its international problems that avoided violent conflict and potential planetary self-immolation. Klaatuthe-alien-emissary was interested in global, not national or local issues. As he testily complained to the President's representative, Mr. Harley (Frank Conroy), who tried to explain Earth's Cold War politics involving "tensions and suspicions," "I'm not concerned, Mr. Harley, with the internal affairs of your planet. My mission here is not to solve your petty squabbles. It concerns the existence of every last creature on Earth." As Tony Magistrale put it: "All this impotent bureaucratic representative is capable of doing...is lamenting the general stubbornness among worldly leaders and the profound provincialism of the human race" (85), which left Klaatu very unimpressed (see Figure 7).

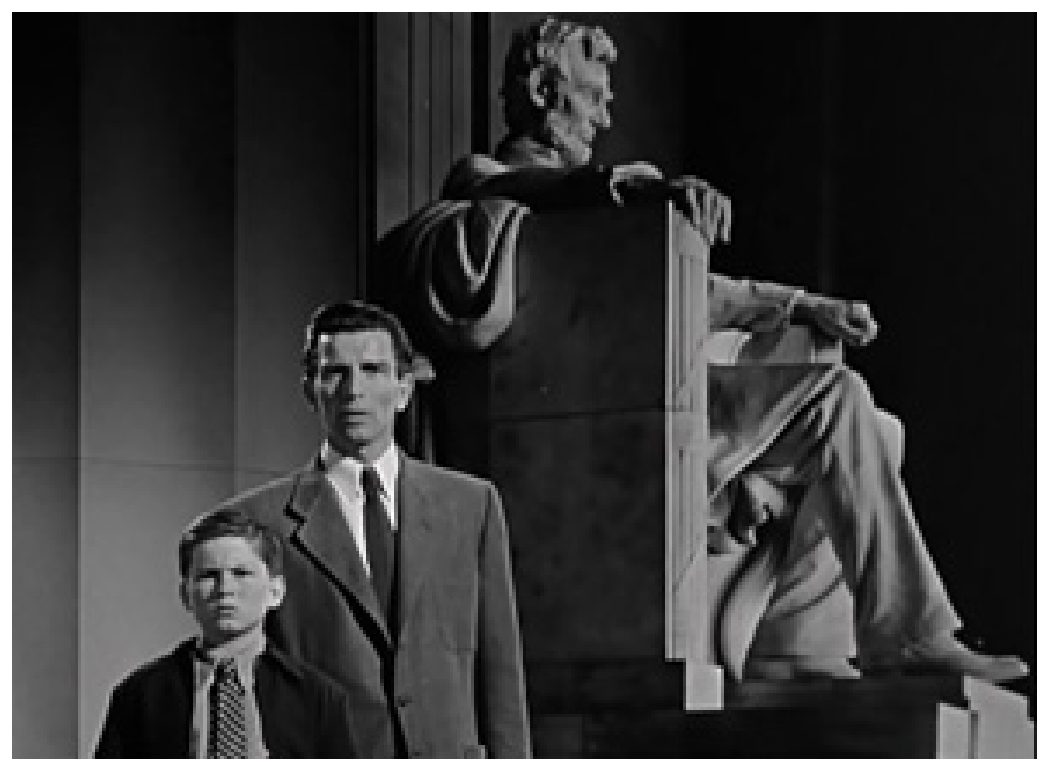

Figure 6: Bobby and Klaatu at the Lincoln Memorial

Furthermore, when Mr. Harley suggested the avoidance of the "evil forces," Klaatu refused to be politicised for partisan ends, for he curtly replied: "I will not speak with any one nation or group of nations. I don't intend to add my contribution to your childish jealousies and suspicions." As he later confessed: "I'm impatient with stupidity. My people have learned to live without it." He was referring to the politicking and socio-political ineffectiveness of human governance that hampered him meeting with all the leaders of the world. Mr. Harley tellingly responded: "I'm afraid my people haven't [learned to live without stupidity]. I'm very sorry. I wish it were otherwise."

Klaatu was more concerned about Earth's rudimentary atomic energy linked to rocket-space ships. As he told Prof. Barnhardt: "That will create a threat to the peace and security of other planets, that of course we cannot tolerate...I came here to warn you that by threatening danger, your planet faces danger. Very grave danger. I'm prepared however to offer a solution." Klaatu speaks with authority, which is "not combative and imperialistic but as peace-making" (Cranny-Francis 85). However, he combined his message with impatience and patience, condescension and hopefulness, respect and despair!

Klaatu is not against emotions per se as Jancovich (41-42) asserted. Rather, Klaatu is against stupidity (nuclear and otherwise), just as he claimed, and he and the confederation of other planets must be very concerned (emotional?) about the issue because he travelled for approximately five (earth) months and covered over 250 million (earth) miles to get to our planet and give humanity a piece of his mind! For Garyn G. Roberts, The Day the Earth Stood Still was the "most conscious, intense and profound object lesson" (135) 
of the "idea of the superior being (in terms of intelligence) thwarting the foolishness of humanity" (135). For Ziauddin Sardar, Klaatu's alien otherness makes "outer space the real home of Western epistemology and metaphysics" (12), especially as it cinematically canvassed social, moral and political philosophy as well as technology-and-ethics issues (Skoble).

\section{The Day the Earth Stood Still as a Religious Film}

For all its noble intent and critique of nationalism, militarism and planetary ethnocentrism, it is an exceptional film and worthy of respect today because of it. However, it was an even more significant film for deliberately crafting a sacred subtext into the narrative which turned this UFO/political/AI/police/philosophical story into a "filmic morality play" (Nicolosi 9). It provides "a Biblical solution to the nuclear crisis" (Shapiro Atomic 80) by crafting powerful christic resonances within its storyline. These additional layers of religious meaning helped propel this SF film into cult status, even if viewers did not know exactly why it affected them so profoundly.

As John Brosnan confessed: "What my younger self missed on that first viewing of the movie was that the plot parallels the story of Jesus Christ...but, strangely enough, no one noticed the parallel at the time of the film's release, not even the director, Robert Wise" (Primal 60-61). Even today "the Christ-like 'Carpenter'" (Kaye and Hunter 2) is frequently overlooked. For example, Douglas Curran argued that:

The degree to which the mythology of the flying saucer has been integrated into contemporary culture can be illustrated by comparing the 1951 film The Day the Earth Stood still with Steven Spielberg's 1977 production, Close Encounters of the Third Kind. In the former, a handsome, benevolent being from a utopian planet lands his flying saucer near the White House to bring the message to Earthlings that atomic testing is harming other planets. Reacting with fear and hostility, the people of Earth attempt to destroy him. The alien escapes, mingles with the populace, and eventually is able to relay his message to top scientists. Steven Spielberg, a member of the baby boomer generation who grew up with flying saucers, conceived his 1977 classic differently, with humanity eagerly anticipating the visit from outer space. The alien ship of Close Encounters descends in a blaze of light that suggests the second coming of Christ (20).

Similarly, Klaatu's glowing spaceship ascending into the heavens at the film's end suggests the ascension of Jesus Christ and anticipates his second coming in a yet-to-be-realised sequel. Not only was The Day the Earth Stood Still a "prophetic classic" (Craft 217) with christic overtones, but it also had very "distinct religious parallels" (Woolley 52) throughout its storyline, which once sensitised to them, "the religious parallel becomes embarrassing after a while" (127) according to Carlos Clarens.

This claim is understandable when one discovers that The Day the Earth Stood Still was deliberately crafted to make Klaatu an alien Messiah, and thus the dominant intertextual appeal of the film. In fact, its scriptwriter Edmund H. North "only discussed the biblical interpretation decades later after auteurist/archaeologistcritics had unearthed it" (Frumkes 34). Yet, it is somewhat ironic that its deliberately designed religious nature is not well-known amongst religious communities, even though the Klaatu-Christ parallel is very well known amongst secular SF fans; especially Klaatu's hi-tech resurrection scene (Figure 8).

Notwithstanding Curran (20), nowadays, mentioning the film's christic nature is almost obligatory for any serious SF critic-commentator. For example, Patrick Lucanio argued that the film "offers allusions to the apocalypse, and its hero's plight to save mankind in spite of itself owes much of its structure to the New Testament" (26) whilst Ziauddin Sardar noted that Klaatu "could be interpreted as a biblical prophet" (12; see also Fischer 684; Shapiro Universal 104).

At the very least, Jerome F. Shapiro considered Klaatu/Mr. Carpenter to be a "supernatural being...[a] supernatural messenger" (Atomic 81), and so for John C. Lyden, he "is not to be feared and that he represents our better nature, what we might become if we control our violence" (206). Just like Christians today who try to emulate the gentle Jesus. Some commentators though, tended to inappropriately conflate "God" (i.e., the creator of existence) and "Jesus" (i.e., the son of God) within "its almost biblical narrative" (Woolley 52). For example, King and Krzywinska stated:

The 'good' alien of science fiction sometimes takes on the patina of a kind of God figure, Klaatu in The Day the Earth Stood Still adopts the name Carpenter, 'goes among the people', is killed, 


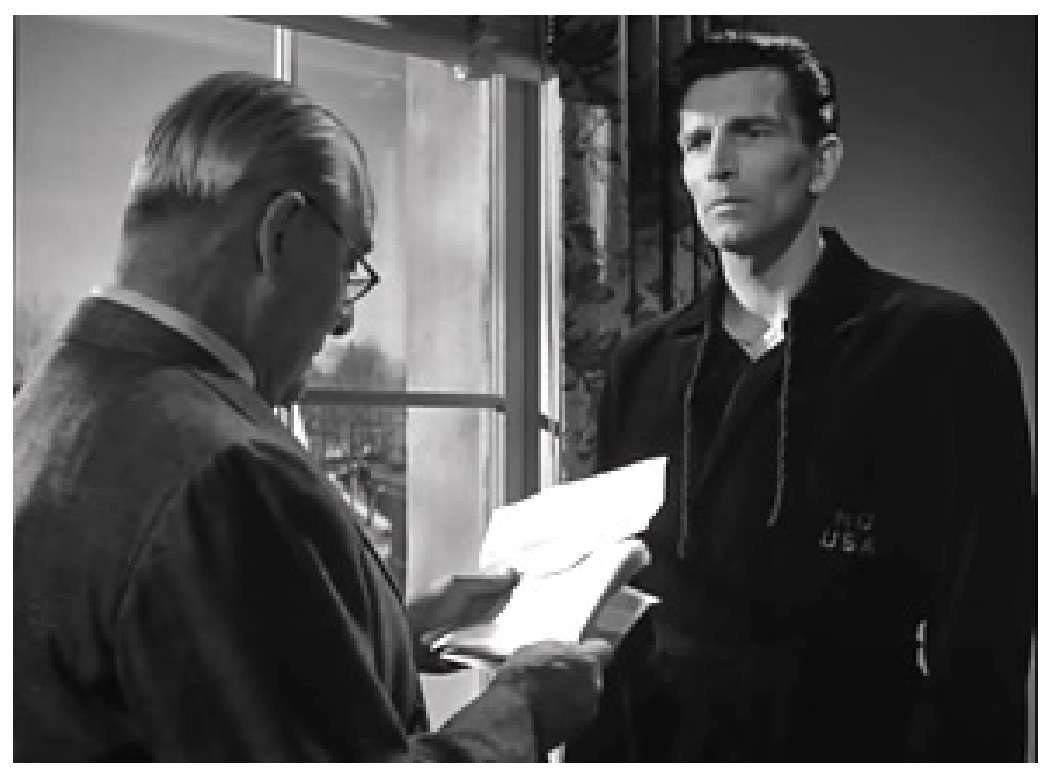

Figure 7: An Unimpressed Klaatu with Mr. Harley

resurrected and ascends into the sky: clearly established as Christ-like (33).

Nevertheless, the film's semi-documentary style, Christ-figure subject matter, apocalyptic theme, religious resonances, and foreboding neo-film noir sense of immediacy made it one of the best subtextual SF biopics of Jesus in existence today. It is certainly worthy of inclusion alongside E.T.: The Extra-Terrestrial, K-Pax, The Matrix, Starman, Superman: The Movie, Twelve Monkeys and their lesser Christ-figure brothers and sisters. Even its director Robert Wise belatedly acknowledged this religious fact during an interview in 1976 when he said: "I can see now why people would notice it...Michael Rennie had that [Jesus] quality in his performance" (quoted in Brosnan Primal 61). Whilst in 1998, Wise more forcefully stated: "Some people read a religious connotation into the thing, the resurrection and all. If you want to put a beard on [Michael] Rennie and all he could be a Christ figure" (Kreisler par. 4). This fact was especially outstanding for in "the cosmology of the 1950s science fiction movies, extraterrestrials seemed more temperamentally akin to the denizens of hell" (Brain 226) rather than servants of heaven.

\section{Conclusion}

The Day the Earth Stood Still is a UFO film with powerful political, AI, police and philosophical dimensions; however, it is more fully appreciated as a religious film in contemporary scientific garb. Instead of invoking the demonology of the alien other, it provided the subtextual iconography of the divine. This was in the form of Klaatu as a deliberately crafted alien Messiah, and whose primary "purpose is not the destruction of earth but rather its salvation and preparation for entrance into an enlightened extraterrestrial community" (Torry 12) of the heaven-on-Earth variety. Indeed, in the forthcoming instalments of this analytical triptych it will be demonstrated that Klaatu was a very profound Christ-figure, ${ }^{(2)}$ his on-screen associates were heavily biblical, and The Day the Earth Stood Still was deliberately crafted as a complex Christ cycle film.

\section{Notes}

1. Although there are real ontological differences between "cinema," "film," "movie," "video," "TV movie," "CD," "VCD," "DVD," "AVI," "Mpeg-4," "Internet movie" etc., they all deal with audiovisual images and will be treated herein as essentially interchangeable.

2, "And like many actors who play Jesus Christ, Rennie never seemed to have escaped the role of the holy Klaatu" (Brosnan Primal 61). Leonard Nimoy considered it to be "a landmark film" (162) with Michael 


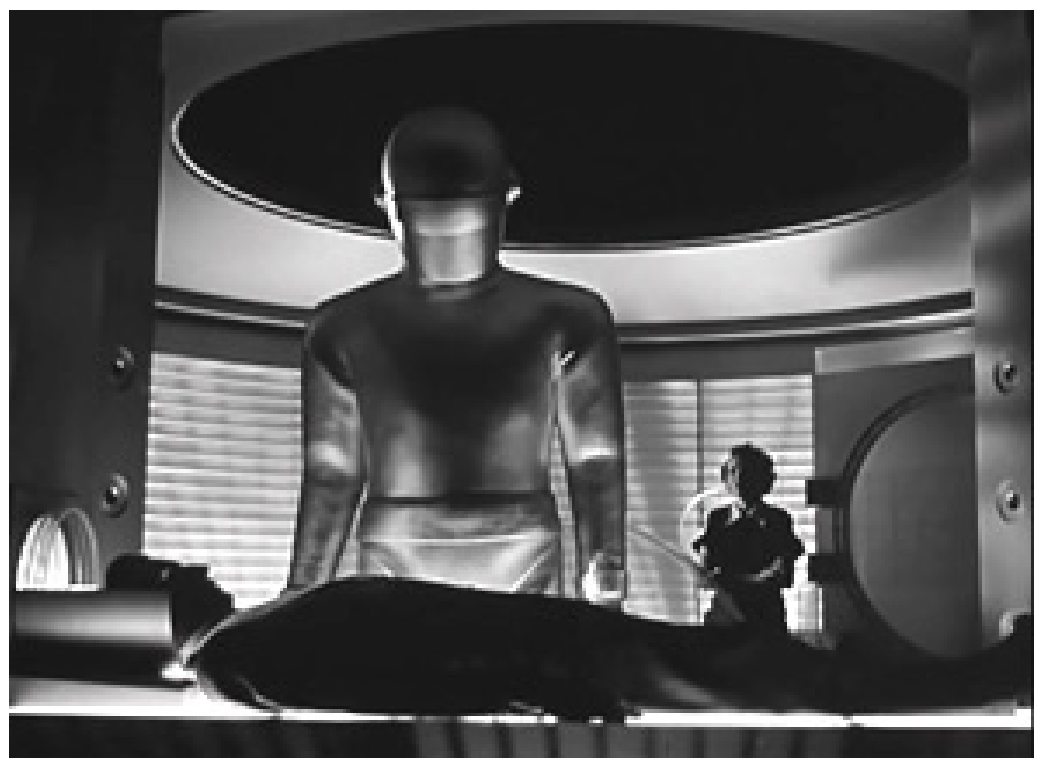

Figure 8: Klaatu being resurrected

Rennie so striking that his Spock character from the Star Trek TV and movie franchise was directly related to him (Naha 260).

\section{References}

Baker, Alan. The Encyclopedia of Alien Encounters. New York, NY: Checkmark Books, 2000.

Barone, Dennis. "Klaatu was No Angel: A Historical-Contextual Analysis of The Day the Earth Stood Still." Studies in the Humanities 23.2 (1996): 202-12.

Bates, Harry. "Farewell to the Master." Reel Future. Eds. Forrest J. Ackerman and Jean Stine. New York: Barnes and Noble, 1994. 146-79.

Bell-Metereau, Rebecca. "The Capital Shape of Science Fiction Heroes to Come." Cinema and Modernity. Ed. Murray Pomerance. New Brunswick: Rutgers UP, 2006. 110-29.

Biskind, Peter. Seeing is Believing: How Hollywood Taught us to Stop Worrying and Love the Fifties. New York: Pantheon Books, 1983.

Brain, Bonnie. "Saviors and Scientists: Extraterrestrials in Recent Science Fiction Films." Et cetera 40.2 (1983): 218-29.

Broderick, Mick. Nuclear Movies: A Filmography. Northcote, VIC: Post-modem, 1988.

Brosnan, John. Future Tense: The Cinema of Science Fiction. London: Macdonald and Jane's, 1978.

"The Day the Earth Stood Still." The Science Fiction Encyclopedia. Ed. Peter Nicholls. Garden City, NY: Dolphin Books, 1979. 156-57.

The Primal Screen: A History of Science Fiction Film. London: Orbit Books, 1991.

Bywater, Tim, and Thomas Sobchack. An Introduction to Film Criticism: Major Critical Approaches to Narrative Film. New York: Longman, 1989.

Cettl, Robert. Terrorism in American Cinema: An Analytical Filmography, 1960-2008. Jefferson, NC: McFarland \& Company, 2009. 
Clarens, Carlos. An Illustrated History of the Horror Film. New York: G. P. Putnam's Sons, 1967.

Coates, Paul. Cinema, Religion and the Romantic Legacy. Aldershot: Ashgate, 2003.

Cousineau, Phil. UFOs: A Manual for the Millennium. New York, NY: HarperCollins West, 1995.

Craft, Michael. Alien Impact: A Comprehensive Look at the Evidence of Human-Alien Contact. New York: St. Martin's P, 1996.

Cranny-Francis, Anne. Multimedia: Texts and Contexts. London: Sage, 2005.

Curran, Douglas. In Advance of the Landing: Folk Concepts of Outer Space. New York: Abbeville P, 2001.

Dick, Bernard F. Anatomy of Film, $3^{\text {rd }}$ ed. New York: St. Martin's P, 1998.

Dubeck, Leroy W., Suzanne E. Moshier, and Judith E. Boss. Science in Cinema: Teaching Science Fact through Science Fiction Films. New York: Teachers College P, 1988.

Ellis, Robert. "Movies and Meaning." The Expository Times 112.9 (2001): 304-08.

Fischer, Dennis. Science Fiction Film Directors, 1895-1998. Jefferson, NC: McFarland, 2000.

Flesher, Paul V. M., and Robert Torry. "Teaching Religion and Film." Journal of Religion and Film 2.3 (1998): http://www.unomaha.edu/jrf/Fleshart.htm. Online March 27, 2013.

Forshey, Gerald. E. "The Apocalyptic Mood in Contemporary Films." Explor: A Journal of Theology 4.1 (1978): 28-38.

Frumkes, Roy. "Those Elite Laser Specials." Films in Review 46.7/8 (1995): 31-34.

Gabbard, Krin. "Religious and Political Allegory in Robert Wise's The Day the Earth Stood Still." Literature/Film Quarterly 10.3 (1982): 150-54.

Gallagher, Michael P. "Theology, Discernment and Cinema." New Image of Religious Film. Ed. John R. May. Kansas City: Sheed \& Ward, 1997. 151-60.

Gianos, Phillip L. Politics and Politicians in American Film. Westport, CT: Praeger, 1999.

Hendershot, Cynthia. Paranoia, the Bomb, and 1950s Science Fiction Films. Bowling Green, OH: Bowling Green State U Popular P, 1999.

Henriksen, Margot A. Dr. Strangelove's America: Society and Culture in the Atomic Age. Berkeley: U of California P, 1997.

Hewitson, James. "Film." Encyclopedia of Millennialism and Millennial Movements." Ed. Richard A. Landes. New York: Routledge, 2006. 280-86.

Howard, David. How to Build a Great Screenplay: A Master Class in Storytelling for Film. New York: St. Martin's P, 2004.

Humphries-Brooks, Stephenson. Cinematic Savior: Hollywood's Making of the American Christ. Westport, CT: Praeger, 2006.

Husarik, Stephen. "Suspended Motion in the Title Scene from The Day the Earth Stood Still." Sounds of the Future - Essays on Music in Science Fiction Film. Ed. Mathew J. Bartkowiak. Jefferson, NC: McFarland, 2010. 164-76.

Jancovich, Mark. Rational Fears: American Horror in the 1950s. Manchester: Manchester UP, 1996.

Jowett, Gart S. "Hollywood, Propaganda and the Bomb: Nuclear Images in Post World War II Films." Film E History 18.2 (1988): 26-38.

Kaye, Heidi, and I. Q. Hunter. "Introduction - Alien Identities: Exploring Difference in Film and Fiction." Alien Identities: Exploring Difference in Film and Fiction. Eds. Deborah Cartmell, I. Q. Hunter, Heidi Kaye and Imelda Whelehan. London: Pluto P, 1999. 1-10. 
King, Geoff, and Tanya Krzywinska. Science Fiction Cinema: From Outer space to Cyberspace. London: Wallflower, 2000.

Kinnard, Roy, and Tim Davis. Divine Images: A History of Jesus on the Screen. New York, NY: Citadel P, 1992.

Kozlovic, Anton K. "Technophobic Themes in Pre-1990 Computer Films." Science as Culture 12.3 (2003): 341-73.

. "The Structural Characteristics of the Cinematic Christ-figure." Journal of Religion and Popular Culture 8.Fall (2004): http://www.usask.ca/relst/jrpc/art8-cinematicchrist-print.html

Kreisler, Harry. The Wise Touch: Conversation with Robert Wise. February 28, 1998. Wise Films: The Day the Earth Stood Still."

http://globetrotter.berkeley.edu/conversations/Wise/wise-con7.html. Online March 27, 2013.

Lewis, James R. UFOs and Popular Culture: An Encyclopedia of Contemporary Myth. Santa Barbara, CA: ABC-CLIO, 2000.

Lucanio, Patrick. Them or Us: Archetypal Interpretations of Fifties Alien Invasion Films. Bloomington: Indiana UP, 1987.

Lyden, John C. Film as Religion: Myths, Morals, and Rituals. New York: New York UP, 2003.

Magistrale, Tony. Abject Terrors: Surveying the Modern and Postmodern Horror Film. New York: Peter Lang, 2005.

Malone, Peter. "Jesus on Our Screens." New Image of Religious Film. Ed. John R. May. Kansas City: Sheed \& Ward, 1997. 57-71.

McMillan, Barry. "24 Frames... - Film Notes." The Furrow: A Journal for the Contemporary Church 53.6 (2002): 360-62.

Morris, Peter J. Aliens Among Us: A Beginner's Guide. Abingdon: Hodder \& Stoughton, 2005.

Naha, Ed. "The Inner Search for Spock: An Interview with Leonard Nimoy." Omni's Screen Flights/Screen Fantasies: The Future According to Science Fiction Cinema. Ed. Danny Peary. Garden City, NY: Doubleday, 1984. 260-67.

Nash, Jay R., and Stanley R. Ross, eds. The Motion Picture Guide. C-D. 1927-1983. Chicago: Cinebooks, 1985 .

Nicolosi, Barbara R. "Visions of Faith and Fear." Liguorian 88 (2000): 8-9.

Nimoy, Leonard. I am Spock. London: Century, 1995.

Perkowitz, Sidney. Hollywood Science: Movies, Science and the End of the World. New York: Columbia UP, 2007.

Pfeiffer, Lee. The Complete Idiot's Guide to Classic Movies. New York, NY: Alpha, 2006.

Pohl, Frederick, and Frederick Pohl IV. Science Fiction Studies in Film. New York, NY: Ace Books, 1981.

Reinhartz, Adele. "Jesus on the Silver Screen." Revelation: Representations of Christ in Photography. Ed. Nissan N. Perez. London: Merrell/The Israel Museum, Jerusalem, 2003. 186-89.

Jesus of Hollywood. New York, NY: Oxford UP, 2007.

Roberts, Garyn G. "Revelation, Humanity, and a Warning: Four Motifs of 1950s Science Fiction Invasion Films." Beyond the Stars II: Plot Conventions in American Popular Film. Eds. Paul Loukides and Linda K. Fuller. Bowling Green, OH: Bowling Green State UP, 1991. 130-42.

Rogerson, Peter. "The Mythology of UFO Events and Interpretations: A New Examination." Merseyside UFO Bulletin 5.3 (1972): 
http://magonia.haaan.com/2008/the-mythology-of-ufo-events-and-interpretations-a-new-examination-peterrogerson.

Ruppersburg, Hugh. "The Alien Messiah in Recent Science Fiction Films." Journal of Popular Film E Television 14.4 (1987): 159-66.

Sardar, Ziauddin. "Introduction." Aliens R Us: The Other in Science Fiction Cinema. Eds. Ziauddin Sardar and Sean Cubitt. London: Pluto P, 2002. 1-17.

Shapiro, Benjamin. "Universal Truths: Cultural Myths and Generic Adaptation in 1950s Science Fiction Films." Journal of Popular Film and Television 18.3 (1990): 103-11.

Shapiro, Jerome F. Atomic Bomb Cinema: The Apocalyptic Imagination on Film. New York: Routledge, 2002 .

Shaw, James. The Day the Earth Stood Still: Dramatizing a Political Tract. Creative Screenwriting 5.4 (1998): 50-53.

Siegel, Richard, and Jean-Claude Suares. Alien Creatures. Sydney: Harper \& Row, 1978.

Simpson, Paul. The Rough Guide to Cult Movies. London: Haymarket Customer Publishing/Rough Guides, 2002 .

Skoble, Aeon J. "Technology and Ethics in The Day the Earth Stood Still." The Philosophy of Science Fiction Film. Ed. Steven M. Sanders. Lexington, KY: UP of Kentucky, 2008. 91-101.

Sobchack, Vivian. Screening Space: The American Science Fiction Film, $2^{\text {nd }}$ ed. New York: Ungar, 1987.

Spencer, John, comp and ed. The UFO Encyclopedia. London: Headline, 1991.

Stacy, Jan, and Ryder Syversten. The Great Book of Movie Monsters. Bromley, Kent: Columbus Books, 1983.

Stal. "The Day the Earth Stood Still [5 September 1951]." Variety Film Reviews 1949-1953. Volume Eight. New York: Garland Publishing, 1983. Npn.

Stern, Richard C., Clayton N. Jefford, and Guerric DeBona. Savior on the Silver Screen. New York: Paulist P, 1999 .

Stone, Jon R. "'Apocalyptic" Themes on the Silver Screen." God in the Details: American Religion in Popular Culture. Eds. Eric M. Mazur and Kate McCarthy. New York: Routledge, 2001. 65-82.

Tatum, W. Barnes. Jesus at the Movies: A Guide to the First Hundred Years. Revised and Expanded. Santa Rosa, CA: Polebridge P, 2004.

Telotte, J. P. Replications: A Robotic History of the Science Fiction Film. Urbana: U of Illinois P, 1995. . Science Fiction Film. Cambridge: Cambridge UP, 2001.

Tompkins, Boylston. "Introduction." Alien Creatures. Eds. Richard Siegel and Jean-Claude Suares. Sydney: Harper \& Row, 1978. 7-32.

Torry, Robert. "Apocalypse Then: Benefits of the Bomb in Fifties Science Fiction Films." Cinema Journal 31.1 (1991): 7-21.

Walsh, Richard. Reading the Gospels in the Dark: Portrayals of Jesus in Film. Harrisburg: Trinity P International, 2003.

Woolley, Steve. "The Day the Earth Stood Still." There's Something Going on Out There. Ed. Ann Lloyd. London: Orbis, 1982. 52-53.

Zebrowski, George. "The Day the Earth Stood Still (1951)." The New Encyclopedia of Science Fiction. Ed. James Gunn. New York: Viking, 1988. 121-22. 


\section{Filmography}

Babette's Feast (1987, dir. Gabriel Axel)

Close Encounters of the Third Kind (1977, dir. Steven Spielberg)

E.T.: The Extra-Terrestrial (1982, dir. Steven Spielberg)

Forbidden Plant (1956, dir. Fred McLeod Wilcox)

Independence Day (1983, dir. Roland Emmerich)

Invasion of the Body Snatchers (1956, dir. Don Siegel)

K-Pax (2001, dir. Iain Softley)

Lost in Space (1998, dir. Stephen Hopkins)

Metropolis (1926, dir. Fritz Lang)

Nell (1994, dir. Michael Apted)

Pleasantville (1998, dir. Gary Ross)

Samson and Delilah (1949, dir. Cecil B. DeMille)

Starman (1984, dir. John Carpenter)

Superman: The Movie (aka Superman) (1978, dir. Richard Donner)

The Day the Earth Stood Still (1951, dir. Robert Wise)

The Flintstones in Viva Rock Vegas (2000, dir. Brian Levant)

The Matrix (1999, dir. Andy \& Larry Wachowski)

The Rocky Horror Picture Show (1975, dir. Jim Sharman)

The Thing [aka The Thing from Another World] (1951, dir. Christian Nyby)

The Truman Show (1998, dir. Peter Weir)

Twelve Monkeys (1995, dir. Terry Gilliam)

\section{Author Information}

Anton Karl KOZLOVIC (PhD Flinders) researches in the Screen Studies department, School of Humanities at Flinders University (Adelaide, Australia). His interests include religion-and-film, computer films, and the biblical cinema of Cecil B. DeMille. He has published in journals including Australian Religion Studies Review, Belphegor: Popular Literature and Media Culture, The Film Journal, Journal of Contemporary Religion, The Journal of Religion and Film. 